\title{
How and what do medical students learn in clerkships? Experience-based learning (ExBL)
}

Citation for published version (APA):

Boshuizen, H., Dornan, T., Tan, N., Gick, R., Isba, R., Mann, K., Scherpbier, A., Spencer, J., \& Timmins, E. (2014). How and what do medical students learn in clerkships? Experience-based learning (ExBL). Advances in Health Sciences Education, 19(5), 721-749. https://doi.org/10.1007/s10459-014-9501-0

DOI:

10.1007/s10459-014-9501-0

Document status and date:

Published: 01/12/2014

Document Version:

Peer reviewed version

Please check the document version of this publication:

- A submitted manuscript is the version of the article upon submission and before peer-review. There can be important differences between the submitted version and the official published version of record. People interested in the research are advised to contact the author for the final version of the publication, or visit the DOI to the publisher's website.

- The final author version and the galley proof are versions of the publication after peer review.

- The final published version features the final layout of the paper including the volume, issue and page numbers.

Link to publication

\section{General rights}

Copyright and moral rights for the publications made accessible in the public portal are retained by the authors and/or other copyright owners and it is a condition of accessing publications that users recognise and abide by the legal requirements associated with these rights.

- Users may download and print one copy of any publication from the public portal for the purpose of private study or research.

- You may not further distribute the material or use it for any profit-making activity or commercial gain

- You may freely distribute the URL identifying the publication in the public portal.

If the publication is distributed under the terms of Article 25fa of the Dutch Copyright Act, indicated by the "Taverne" license above, please follow below link for the End User Agreement:

https://www.ou.nl/taverne-agreement

Take down policy

If you believe that this document breaches copyright please contact us at:

pure-support@ou.nl

providing details and we will investigate your claim.

Downloaded from https://research.ou.nl/ on date: 26 Apr. 2023 


\title{
How and what do medical students learn in clerkships? Experience based learning (ExBL)
}

\author{
Tim Dornan • Naomi Tan • Henny Boshuizen • Rachel Gick • Rachel Isba • Karen Mann • \\ Albert Scherpbier • John Spencer • Elizabeth Timmins
}

\begin{abstract}
Clerkship education has been called a 'black box' because so little is known about what, how, and under which conditions students learn. Our aim was to develop a blueprint for education in ambulatory and inpatient settings, and in single encounters, traditional rotations, or longitudinal experiences. We identified 548 causal links between conditions, processes, and outcomes of clerkship education in 168 empirical papers pub- lished over 7 years and synthesised a theory of how students learn. They do so when they are given affective, pedagogic, and organisational support. Affective support comes from doctors' and many other health workers' interactions with students. Pedagogic support comes from informal interactions and modelling as well as doctors' teaching, supervision, and precepting. Organisational support comes from every tier of a curriculum. Core learning processes of observing, rehearsing, and contributing to authentic clinical activities take place within triadic relationships between students, patients, and practitioners. The phrase 'supported participation in practice' best describes the educational process. Much of the learning that results is too tacit, complex, contextualised, and individual to be defined as a set of competencies. We conclude that clerkship education takes place within rela- tionships between students, patients, and doctors, supported by informal, individual, contextualised, and affective elements of the learned curriculum, alongside formal, standardised elements of the taught and assessed curriculum. This research provides a blueprint for designing and evaluating clerkship curricula as well as helping patients, students, and practitioners collaborate in educating tomorrow's doctors.
\end{abstract}

